\title{
SUBJEK HUKUM ATAS PELAYANAN KONTRASEPSI DALAM PELAKSANAAN PROGRAM KELUARGA BERENCANA
}

Oleh:

Joko Nur Sariono

\begin{abstract}
Subyek Law gave by the authority for contraception service in execution program the KB is doctor and midwife arranged in Regulation of Minister for Public Health R.I. and Rights and obligations in execution of contraception service program the Family Berencana go into effect reciprocally, its meaning is rights for health energy represent the obligation of acceptor $K B$ so on the contrary rights for acceptor $K B$ represent the obligation of health energy.
\end{abstract}

Keyword : Contraception Service, Rights And Obligations OfAcceptor Kb, Program The Family Berencana

\section{PENDAHULUAN}

Hukum sebagai peraturan atau kaidah mengenai perilaku manusia mengandung isi yang bersifat umum dan normatif. Umum karena berlaku bagi setiap orang dan normatif karena menentukan apa yang seharusnya dilakukan dan apa yang tidak boleh dilakukan juga menentukan bagaimana caranya untuk melaksanakan patuh kepada kaidah-kaidah. (Sudikno Mirtokusumo, 1991: 39). Oleh karena itu dalam kaitannya dengan tulisan ini yang dimaksudkan dengan hukum adalah hukum obyektif yang berupa semua peraturan hukum tertulis yang berlaku dalam masyarakat.

$$
\text { Hukum kependudukan atau }
$$

"Population Law" menurut Luke T. Lee diartikan sebagai bidang-bidang hukum yang langsung atau tidak langsung ada kaitannya dengan pengaturan pertumbuhan dan penyebaran penduduk serta aspek-aspek kesejahteraan, yang mempengaruhi dan dipengaruhi oleh jumlah penyebaran penduduk. (Hermien Hadiati Koeswadji, $1988: 7$ )

Batasan pengertian mengenai hukum kependudukan tersebut ke-mudian di sempurnakan oleh D.C. Jayasurya sebagai "The body of laws and regulations which has a bearing on population dynamics", 
a) by regulation the growth, composition, and move ment of the population; and

b) by Inducing behavioral and attitudinal changes in individuals with a view to enhancing the quality of life, both at the microlevel of the family unit and at the macrolevel of the community or nation. (Hermien Hadiati Koeswadji, $1988: 7$ )

Untuk memecahkan permasalahan kependudukan melalui pendekatan hukum. Rebecca J. Cook telah mengemukakan 3 (tiga) model cara pendekatan dalam menjelaskan peranan hukum dalam menangani permasalahan kependudukan yaitu :

1. "The Family Planning Model" ;

2. "The Population Control Model";

3. "The Economic Development Model".

(Rebecca J. Cook, 1973:86)

"The Family Planning Model" juga dikenal dengan model Keluarga Berencana, yaitu suatu model pendekatan yang berkaitan dengan penyediaan perawatan kesehatan berupa alat-alat kontrasepsi atas dasar suka rela dan pelayanan kesehatan ibu dan anakanak. Pendekatan ini selanjutnya dijelaskan oleh Kingsley Davis bahwa Keluarga Berencana (selanjutnya disingkat KB) merupakan istilah lain bagi kontrasepsi, karena pendekatanpendekataan yang digunakan dalam pelayanan KB berakibat membatasi jumlah kelahiran. (Sembiring1985 : 152)

Di Indonesia dasar-dasar kebijaksanaan kependudukan melalui pendekatan KB tersebut dapat ditemukan dalam Ketetapan MPR No. IV/MPR/1978 tentang GBHN yang menyebutkan bahwa:

"Agar Pembangunan ekonomi dan peningkatan kese jahteraan rakyat dapat terlaksana dengan cepat, harus disertai dengan pengaturan pertumbuhan jumlah penduduk melalui program $\mathrm{KB}$, yang muntlak harus dilaksanakan dengan berhasil karena kegagalan pelaksanaan KB akan meng-akibatkan hasil usaha pem-bangunan menjadi tidak berarti dan dapat membahayakan generasi yang akan datang".

Dalam perkembangannya kemudian dibentuk Badan Koordinasi Keluarga Berencana (selanjutnya disingkat BKKBN) berdasarkan Keputusan Presiden Nomor 8 tahun 1970 tentang Pembentukan Badan Koordinasi 
$\mathrm{KB}$, yang kemudian diperbaharui dengan Keputusan Presiden No.109 Tahun 1993, bertanggung jawab untuk mengkordinir semua kegiatan program KB yang utamanya bertujuan untuk mengendalikan laju pertambahan penduduk melalui penurunan angka atau jumlah kelahiran dengan menggunakan alat Kontrasepsi.

Untuk mendukung kebijaksanaan tersebut, beberapa peraturan perundang-undangan telah dikeluarkan, khususnya dalam rangka memecahkan permasalahan ke-pendudukan dan KB di Indonesia diantaranya ialah:

1. Dikeluarkannya Undang-Undang No.10 tahun 1992 tentang Perkembangan Kependudukan Dan Pembangunan Keluarga Sejahtera, (Lembaran Negara tahun 1992 nomor 35 dan Tambahan Lembaran Negara nomor 3475); (selanjutnya disingkat UU No.10 Th.1992)

2. Dikeluarkannya Undang-undang No.23 tahun 1992 tentang Kesehataan (Lembaran Negara tahun 1992 nomor 100, Tambahan Lembaran Negara No.3495); (selanjutnya disingkat UU No. 23 Th.1992).

\section{PERMASALAHAN}

Dari uraian tersebut di atas permasalahan dapat dirumuskan sebagai berikut:

1. Siapakah subyek hukum atas pelayanan kontrasepsi dalam pelaksanaan program Keluarga Berencana?

2. Apa saja hak dan kewajiban subjek hukum atas pelayanan kontrasepsi yang diberikan dalam pelaksanaan program KB?

\section{PEMBAHASAN}

\section{Subyek Dalam Pelaksanaan Pelayanan Program Keluarga Berencana}

Keluarga Berencana (selanjut-nya disebut KB) merupakan istilah lain yang digunakan untuk kontrasepsi karena pendekatan-pendekatan yang digunakan dalam pelaksanaan pelayanan program KB berakibat membatasi jumlah kelahiran. Pelaksanaan pelayanan program KB dilaksanakan oleh BKKBN bekerja sama dengan semua instansi terkait, untuk BKKBN bertugas menyiapkan tenagatenaga profesional untuk melaksanakan tugas tersebut yaitu yang disebut dengan Petugas Lapangan Keluarga Berencana 
(selanjutnya disingkat PLKB).

Sesuai dengan pengertian yang digunakan dalam Surat Edaran bersama kepala BKKBN dan Kepala BAKN Nomor $\mathrm{t}$ 20/SE/1988, Nomor: 4635/OT101/H.1/1988 tanggal 15 Agustus 1988, menyatakan bahwa Penyuluh KB/PLKB adalah pegawai negeri sipil yang diberi tugas melakukan kegiatan penyuluhan KB secara penuh oleh pejabat yang berwenang pada satuan organisasi BKKBN. Dengan kata lain, PLKB adalah petugas khusus BKKBN yang bergerak untuk menghubungi, mengajak dan membina masyarakat secara perorangan, agar mereka ikut secara nyata dalam program KB.(Agustin Widjiastuti, 1996: 13)

Di dalam menjalankan fungsi khususnya yaitu fungsi pelayanan kontrasepsi, PLKB melakukan hubungan koordinasi dengan departemen kesehatan untuk minta bantuan tenaga kesehatan melakukan upaya tertentu untuk mendukung kegiatan pelayanan kontrasepsi yang meliputi, pemberian informasi kepada pemakai atau pengguna alat kontrasepsi (akseptor KB), penggunaan alat-alat kontrasepsi yang tepat dan baik, melakukan pemasangan alat kontrasepsi, melakukan pemeriksaan sekaligus melakukan pemeliharaan.

Dalam penulisan ini, difokuskan pada hubungan hukum antara Tenaga Kesehatan dan akseptor KB berkaitan dengan pelayanan kontrasepsi, pemfokusan ini dimaksudkan utuk membatasi lingkup permasalahan. Di dalam pasal 50 UU No. 23 Tahun 1992 tentang kesehatan menyebutkan:

(1) Tenaga Kesehatan bertugas menyelenggarakan atau melakukan kegiatan kesehatan sesuai dengan bidang keahlian dan atau kewenangan Tenaga Kesehatan yang bersangkutan;

(2) Ketentuan mengenai kategori, jenis dan kualifikasi Tenaga Kesehatan ditetapkan dengan Peraturan Pemerintah.

Sedangkan yang dimaksud dengan Tenaga Kesehatan sebagaimana telah diatur dalam Peraturan Pemerintah R.I. nomor 32 tahun 1996 tentang Tenaga Kesehatan menyebutkan dalam pasal 1, setiap orang yang mengabdikan diri dalam bidang kesehatan serta memiliki pengetahuan dan atau keterampilan melalui pendidikan di bidang kesehatan yang untuk jenis tertentu memerlukan 
kewenangan untuk melakukan upaya kesehatan.

Dalam pasal 2 nya mengatur jenis Tenaga Kesehatan yang terdiri dari:

(1) Tenaga medis, meliputi dokter dan dokter gigi;

(2) Tenaga keperawatan, meliputi perawat dan bidan;

(3)Tenaga kefarmasian, meliputi apoteker, analis farma-si dan asisten apoteker;

(4) Tenaga kesehatan masyarakat, meliputi epidemiolog kesehatan, entomolog kesehatan, mikrobiolog kesehatan, penyuluh kesehatan, administrator kesehatan dan sanitarian;

(5) Tenaga gizi, meliputi nutrisionis dan dietisien;

(6) Tenaga keterapian, meliputi fisioterapis, okupasi-terapis dan terapis wicara;

(7) Tenaga keteknisian medis, meliputi radioterapis, teknisi gigi, teknisi elektromedis, analis kesehatan, refraksionis optisien, otorik prostetik, teknisi tranfusi dan perekam medik.

Tenaga Kesehatan yang berwenang untuk melakukan pelayanan kontrasepsi dalam program KB adalah dokter dan bidan yang diatur dalam Instruksi bersama Menteri Kesehatan R.I. dan Kepala BKKBN No. 346/Menkes IInst/VI/1983 dan No. 296/HK011/E3/1983 tentang Intensifikasi Pelaksanaan Program Kependudukan dan $K B$, dan dalam Peraturan Menteri Kesehatan R.I. No. 363/Menkes/Per /IX/1980 tentang Wewenang Bidan yang diperbarui dalam Peraturan Menteri Kesehatan R.I. No. 572/Menkes/Per/VI/ 1996 tentang Registrasi dan Prektek Bidan.

Di dalam Peraturan Menteri Kesehatan R.I. No. 363/Men.Kes/ Per/lX/1980 tentang Wewenang Bidan, pasal 3 ayat 1 bagian ke 3 menyebutkan bahwa: Seseorang bidan diberi wewenang khusus dan di bawah pengawasan seorang dokter untuk melakukan pertolongan masa nifas yang meliputi :

a. Pemberian antibiotika pada infeksi bai yang dimakan maupun yang diminum;

b. Pemasangan alat kontrasepsi dalam rahim (AKDR);

C. Pemberian kontrasepsi suntikan.

Di samping itu disebutkan pula dalam pasal 3 ayat 2: bahwa dalam melakukan pekerjaan yang dimaksud ayat 1 pasal 3 tersebut, tanggung jawab berada 
pada dokter yang mengawasinya. Pasal 4 menyebutkan bahwa Bidan dalam melakukan pekerjaan yang dimaksud ayat 1 pasal 3 harus berdasarkan wewenang yang diberikan oleh dokter, kecuali dalam keadaan darurat sebagaimana yang dimaksud dalam ayat 1 pasal 6.

Pasal 6 menyebutkan tentang keadaan darurat yakni :

(1) Bidan diberi wewenang untuk melakukan tindakan pertolongan yang dianggap perlu untuk membantu menyelamatkan penderita atas tanggung jawab sendiri;

(2) Segera setelah melakukan tindakan darurat tersebut bidan diwajibkan membuat laporan ke Pusat Kesehatan Masyarakat Wilayah setempat.

Dari ketentuan-ketentuan tersebut jelas bahwa yang berwenang untuk melakukan kontrasepsi dalam pelaksana-an program KB adalah seorang dokter dan bidan yang mendapatkan pelatihan khusus dan yang atas 2 (dua) tindakannya menurut pasal 6 itu di bawah pengawasan seorang dokter, sehingga seorang bidan yang melakukan kontrasepsi dalam program KB bagi akseptornya tidak terlepas dari pengawasan dokter, dan dokter bertanggung jawab atas tindakan bidan yang di bawah pengawasannya.

Dalam perkembangan selanjutnya wewenang bidan di dalam menjalankan fungsinya membantu program pemerintah untuk peningkatan derajat kesehatan masyarakat khususnya kesehatan ibu dan anak serta keluarga berencana bersifat mandiri. Hal ini telah diatur dalam Peraturan Menteri Kesehatan R.I. Nomor. 572/Menkes/Per/VI/1996 tentang Registrasi dan Praktek Bidan. Pasal 22 Permenkes R.I. No. 572 Th. 1996 tersebut menyebutkan bahwa:

Bidan dalam menjalankan prakteknya berwenang untuk memberikan pelayanan yang meliputi:

a. Pelayanan kebidanan;

b. Pelayanan keluarga berencana;

c. Pelayanan kesehatan masyarakat.

Kemudian dalam pasal 27 menyebutkan bahwa pelayanan kebidanan dalam rangka pelaksanaan program keluarga berencana, bidan berwenang untuk:

a. Memberikan obat dan alat kontrasepsi melalui oral, suntikan dan alat kontrasepsi dalam rahim, alat 
kontrasepsi bawah kulit, kondom dan tablet vaginal serta tisue vaginal;

b. Memberikan pelayanan efek sanping pemakaian kontrasepsi ;

c. Melakukan pencabutan alat kontrasepsi dalam rahim letak normal;

d. Melakukan pencabutan AKBK tanpa penyulit.

Di dalam melaksanakan praktek bidan wajib melakukan pencatatan dan pelaporan yang berkaitan dengan pelayanan yang diberikan (pasal 32 Permenkes No.572 th. 1996).

Dengan demikian atas tindakan bidan yang menjalankan fungsinya dalam pelayanan pelaksanaan program KB tidak bertanggung jawab kepada dokter, akan tetapi cukup dengan pencatatan dan pelaporan kepada pembina dan pengawas yaitu Puskesmas, Dinas kesehatan, Kantor Wilayah Departemen Kesehatan sampai Direktorat Jendral, sebagaimana yang diatur dalam pasal 33 Permenkes R.I. tersebut.

\section{Kewajiban dan Hak Tenaga Kesehatan Dalam Pelaksanaan Pelayanan Program Keluarga Berencana}

Kewajiban Tenaga Kesehatan khususnya dalam hal ini dokter dan bidan menurut Fred Ameln dibedakan dalam 3 (tiga) kelompok, yaitu antara lain :

a. Kewajiban yang berhubungan dengan fungsi sosial dari pe-meliharaan kesehatan ("health care"). Dalam melakukan kewajiban ini dokter atau bidan harus selalu memperhitungkan faktor kepentingan masyarakat seperti misalnya mempertimbangkan untuk tidak menulis resep untuk obat-obatan yang tidak begitu perlu.

b. Kewajiban yang berhubungan dengan hak-hak pasien yang dalam hal ini termasuk akseptor KB merupakan kewajiban dokter atau bidan untuk memperhatikan dan menghormati hak-hak pasien, seperti misalnya memberikan informasi kepada akseptor tentang cara kerja dari penggunaan suatu alat kontrasepsi tertentu.

c. Kewajiban yang berhubungan dengan standar profesi medis (kedokteran). Adapun mengenai standar profesi kedokteran ini menurut H.J.J. Leenen ialah sesuai dengan standar profesi medis yang dilakukan secara teliti dan hati-hati sesuai dengan standar medis, sebagai seorang dokter atau bidan yang memiliki kemampuan rata-rata ("Aferace") bila dibandingkan dengan 
dokter atau bidan dari kategori keahlian medis yang sama dan dalam situasi/kondisi yang sama dengan sarana dan fasilitas yang sama untuk mencapai tujuan konkret dari tindakan medis tersebut.

Dapat ditambahkan bahwa mengenai kewajiban bidan di dalam menjalankan profesinya, sebagaimana yang diatur dalam pasal 30 Permenkes R.I. No. 572 Th. 1996, menyebutkan bahwa:

(1) Bidan dalam menjalankan praktek harus sesuai dengan kewenangan yang diberikan berdasarkan pendidikan dan pengalaman dalam memberikan pelayanan berdasarkan standar profesi;

(2) Di samping ketentuan tersebut, juga dalam ayat 10 dinyatakan bahwa bidan dalam melaksanakan praktek sesuai dengan kewenangannya harus:

a. Merujuk kasus yang tidak dapat ditangani;

b. Menyimpan rahasia sesuai dengan peraturan perundangundangan yang berlaku;

c. Meminta persetujuan atas tindakan medis tertentu yang akan dilakukan;

d. Memberikan informasi;

e. Melakukan rekam medik yang baik.

Selanjutnya di dalam pasal 21 menyebutkan bahwa:

(1) Bidan dalam menjalankan praktek perorangan harus memenuhi standar profesi dan mematuhi ketentuan peraturan perundang-undangan yang berlaku;

(2) Bidan dalam menjalankan praktek perorangan harus membantu program pemerintah dalam meningkatkan derajad kesehatan masyarakat khususnya kesehatan ibu dan anak serta keluarga berencana.

Hak dari Tenaga Kesehatan dokter dan bidan dalam pelayanan pelaksanaan program KB menurut Fred Ameln adalah,

1. Hak untuk bekerja menurut standar profesi;

2. Hak menolak pelaksanaan tindakan medis tertentu yang ia tidak dapat mempertanggung jawabkan secara profesional;

3. Hak untuk menolak suatu tindakan medis tertentu yang menurut suara 
hatinya tidak baik;

4. Hak untuk mengakiri hubungan dengan seorang pasien jika ia menilai kerjasama antara dia dengan pasien (termasuk akseptor KB) sudah tidak ada lagi gunanya;

5. Hak atas "Privacy" dokter dan bidan;

6. Hak atas itikat baik;

7. Hak atas balas jasa ;

8. Hak atas "fair play";

9. Hak untuk membela diri;

10. Hak untuk memilih pasien;

11. Hak menolak untuk memberikan keterangan tentang pasien di pengadilan.

\section{Kewajiban dan Hak Bagi Akseptor Program Keluarga Berencana}

Kewajiban pasien (dalam tulisan ini termasuk akseptor KB) menurut Fred Ameln, adalah:

a. Kewajiban untuk memberikan informasi kepada Tenaga Kesehatan dokter dan bidan secara jujur, sehingga dokter dan bidan mempunyai bahan yang cukup untuk mengadakan analisa tentang beberapa keluhan yang dialami;

b. Kewajiban untuk melakukan perintah dokter atau bidan dalam rangka perawatan dan pengobatan;

c. Kewajiban untuk memberikan atau menghormati "privacy" dokter dan bidan;

e. Kewajiban untuk memberikan imbalan jasa kepada dokter, dan bidan serta biaya-biaya lainnya;

f. Kewajiban untuk mentaati peraturan intern rumah sakit.

Hak akseptor KB dalam tulisan ini akan merupakan fokus dalam pembahasan dan analisanya dengan menggunakan pendekatan hukum perundang-undangan dan peraturan-peraturan mengenai kebijaksanaan.

$$
\text { Undang-Undang Dasar } 1945
$$

sebagai hukum dasar yang tertulis dan Pancasila sebagai pandangan hidup dan dasar falsafah bangsa Indonesia, memuat aturan pokok sebagai dasar bagi pemerintah untuk,

a. Menyelenggarakan kehidupan negara (politik); 
b. Menyelenggarakan kesejahteraan sosial (ekonomi).

Dalam pembukaan UUD45 alinea IV dirumuskan tentang tujuan negara yaitu: "Penyelenggaraan kesejahteraan sosial". Rumusan ini erat berkait dengan bidang kependudukan dan kesehatan. Demikian pula pasal 27 UUD 1945 yang menyatakan bahwa "tiap-tiap warga negara berhak atas pekerjaan dan penghidupan yang layak bagi kemanusiaan". Dengan demikian UUD 1945 merupakan dasar hukum untuk menyelenggarakan kependudukan dan kesehatan.

Kebijaksanaan kependudukan tersebut telah mendapatkan pengaturannya dalam bentuk undang-undang, yaitu Undang Undang nomor 10 Tahun 1992 tentang Perkembangan Kependudukan dan Pembangunan Keluarga Sejahtera yang diundangkan pada tanggal 16 April 1992 dengan LN tahun 1992 No. 35, TLN Nomor 3475. Sedangkan kebijaksanaan di bidang kesehatan juga mendapatkan pengaturannya dalam bentuk undangundang yaitu Undang-Undang Nomor 23 Tahun 1992 tentang Kesehatan yang diundangkan pada tanggal 17 September 1992 dengan Lembaran Negara tahun 1992 Nomor 100, Tambahan Lembaran
Negara Nomor 3495.

Bila hak-hak akseptor KB dalam program KB diinventarisir, dan yang selanjutnya telah mendapatkan pengaturannya dalam undang-undang yang ada tersusun sebagai berikut:

\section{a. Hak Akseptor KB untuk memilih macam instrumen/alat kontrasepsi}

Hak ini diatur dalam pasal $18 \mathrm{UU}$ No. 10 Th. 1992 yang menyebutkan bahwa:

$$
\begin{aligned}
& \text { "Setiap pasangan suami isteri dapat } \\
& \text { menentukan pilihannya dalam } \\
& \text { merencanakan dan mengatur jumlah } \\
& \text { anak dan jarak antara kelahiran anak } \\
& \text { yang berlandaskan pada kesadaran } \\
& \text { dan tanggung jawab terhadap } \\
& \text { generasi sekarang dan generasi } \\
& \text { mendatang". }
\end{aligned}
$$

Selanjutnya menurut pasal $19 \mathrm{UU}$ No.10 Th.1992 suami isteri mempunyai hak dan kewajiban yang sama serta kedudukan yang sederajad dalam menentukan cara pengaturan kelahiran.

Hak ini juga terdapat dalam pasal 16 (e) dari UU No. 7 Th. 1984 tentang Pengesahan Konvensi Mengenai Penghapusan Segala Bentuk Diskriminasi Terhadap Wanita menjelaskan perlakuan 
atas dasar kesamaan tersebut, yakni "hak yang sama untuk menentukan secara bebas dan bertanggung jawab jumlah dan penjara-kan kelahiran mereka serta untuk memperoleh penerangan, pendidikan dan sarana-sarana untuk memungkinkan mereka menggunakan hak-hak ini". Ini erat terkait dengan pasal 13 UU No. 23 Tahun. 1992 tentang kesehatan yang memuat pengaturan kelahiran dalam rangka menciptakan keluarga yang sehat dan harmonis. Dalam penjelasan atas pasal tersebut disebutkan bahwa, pengaturan kelahiran merupakan suatu upaya bagi pasangan suami isteri untuk me-rencanakan jumlah ideal anak, jarak kelahiran anak, dan usia ideal perkawinan, serta usia ideal untuk melahirkan anaknya agar dapat hidup sehat. Pembahasan mengenai hak untuk memilih cara pengaturan kelakuan juga terdapat dalam Peraturan Pemerintah R.I. Nomor 21 Tahun 1994 tentang Penyelenggaraan Pembangunan Keluarga Sejahtera yang dalam pasal 16 menyebutkan bahwa:

(1) Pelaksanaan penundaan kehamilan, merencanakan jumlah dan jarak antara kelahiran anak dilakukan sendiri oleh pasangan suami-isteri atas dasar kesadaran dan kesukarelaan.

(2) Pelaksanaan penundaan kehamilan sebagaimana dimaksud dalam ayat (1) dilakukan dengan menggunakan alat, obat dan/atau cara pengaturan kehamilan yang dapat diterima pasangan suami isteri sesuai dengan pilihannya.

Selanjutnya dalam penjelasanya disebutkan bahwa, penggunaan alat, obat, dan cara kontrasepsi yang dapat diterima pasangan suami-isteri sesuai pilihannya ini diartikan bahwa suami isteri mempunyai hak untuk menentukan pilihannya dalam menggunakan alat, obat dan cara kontrasepsi. Meskipun demikian dalam menggunakan alat, obat dan cara kontrasepsi itu sesuai dengan pilihannya masih perlu memperhatikan kesesuaiannya dengan kondisi kesehatan suami-isteri, agar tidak menimbulkan akibat yang tidak diharapkan bagi kesehatan.

\section{b. Hak kesehatan keluarga}

Hak ini meliputi, hak atas pelayanan kesehatan, hak atas perawatan, dilakukan oleh Tenaga Kesehatan yang berwenang, tindakan- 
nya harus sesuai dengan standar profesi kesehatan, dan hak atas informasi. Hak ini terdapat dalam pasal 20 UU No. 10 Th. 1992 tentang Perkembangan Kependudukan dan Pembangunan Keluarga Sejahtera yang menyebutkan bahwa:

(1) Penggunaan alat, obat, dan cara pengaturan kehamilan yang menimbulkan resiko terhadap kesehatan dilakukan atas petunjuk dan atau oleh Tenaga Kesehatan yang berwenang untukitu.

(2) Tata cara penggunaan sebagaimana dimaksud dalam ayat 1 dilakukan menurut standar profesi kesehatan sesuai dengan ketentuan perundang-undangan yang berlaku.

Sedangkan dalam Peraturan

Pemerintah R.I. Nomor 21 Tahun 1994 tentang Penyelenggaraan Pembangunan Keluarga Sejahtera pasal 17 menyebutkan bahwa,

(1) Penggunaan alat, obat dan cara pengaturan kehamilan dilakukan dengan cara yang dapat dipertanggungjawabkan dari segi kesehatan serta memper- timbangkan nilai-nilai etik dan agama.

(2) Penggunaan alat, obat dan cara pengaturan kehamilan yang menimbulkan resiko terhadap kesehatan hanya dapat dilakukan oleh Tenaga Kesehatan yang berwenang berdasarkan standar profesi.

Dalam penjelasan dari pasal tersebut menyebutkan bahwa "Alat, obat, dan cara pengaturan kehamilan yang dapat menimbulkan resiko bagi kesehatan terhadap pemakainnya adalah alat, obat dan cara pengaturan kehamilan yang langsung dapat mempengaruhi anatomi tubuh. Mengingat dalam pelaksanaan penggunaan alat, obat, dan cara pengaturan kehamilan berkaitan erat dengan masalah kesehatan dan agar penggunaan alat, obat dan cara pengaturan kelahiran tersebut tidak menimbulkan bahaya bagi kesehatan, maka cara penggunaan atau metode pelaksanaan tersebut dilakukan atas petunjuk atau/atau oleh Tenaga Kesehatan. Yang dimaksud dengan Tenaga kesehatan di sini adalah sebagaimana yang dimaksud dalam peraturan perundang-undangan di bidang 
kesehatan, dan oleh karenanya Tenaga Kesehatan dalam melaksanakan kewenangannya itu harus tetap berlandaskan pada standar profesi kesehatan yang berlaku.

Atas tindakan medis tertentu yang dilakukan oleh Tenaga Kesehatan dalam pelaksanaan program KB tetap dilakukan sesuai dengan standar profesi kesehatan sebagaimana mestinya, yaitu sebagai mana tercantum dalam pasal 53 ayat 3 Undang-Undang Nomor 23 tahun 1992 yang menyebutkan bahwa "Tenaga kesehatan dalam melakukan tugasnya berkewajiban untuk mematuhi standar profesi dan menghormati hak pasien (termasuk akseptor KB)". Dalam penjelasan pasal tersebut menyatakan bahwa yang dimaksud dengan standar profesi adalah pedoman yang harus dipergunakan sebagai petunjuk dalam menjalankan profesi secara baik. Untuk hal ini, H.J.J. Leenen merumuskan tentang batasan pengertian standar profesi ialah:

1. Tindakan medis tertentu harus hati-hati;

2. Sesuai dengan ukuran medis, unsur ukuran medis ini ditentukan oleh ilmu pengetahuan medis.
Pengertian "ukuran medis" dapat dirumuskan sebagai suatu cara tindakan medis tertentu dalam suatu kasus konkret menurut suatu ukuran tertentu, ukuran mana didasarkan pada ilmu medis dan pengetahuan di bidang medis;

3. Sesuai dengan kemampuan ratarata yang dimiliki oleh dokter pada umumnya dengan kategori keahlian medis yang sama;

4. Dalam kondisi yang sama;

5. Dengan sarana dan upaya yang wajar sesuai dengan tujuan konkret dari tindakan medis tersebut. (Raphaella Diah Imaningrum Susanti, 1994 : 4344.)

Tentang persetujuan tindakan medik ("Informed Consent") dalam pelayanan pelaksanaan program KB menurut Peraturan Menteri Kesehatan R.I. No.585/Men.Kes/Per/IX/ 1989 tentang Persetujuan Tindakan Medik, disebutkan bahwa yang dimaksudkan dengan "Informed consent" atau Persetujuan Tindakan Medik adalah persetujuan yang diberikan oleh pasien atau keluarganya atas dasar penjelasan mengenai tindakan medik yang akan 
dilakukan terhadap pasien tersebut.

Dalam peraturan tersebut disebutkan bahwa setiap tindakan medik yang akan dilakukan terhadap pasien harus diinformasikan terlebih dahulu kepada pasien yang ber-sangkutan, mengapa tindakan medik tersebut perlu dilakukan dan resiko apa yang dapat ditimbulkannya. Informasi yang disampaikan kepada pasien tersebut harus selengkap-lengkapnya, secara jujur dan benar, termasuk keuntungan serta kerugian dari tindakan medik tertentu yang akan dilakukan tersebut.

Namun di dalam pasal 14 Permenkes R.I. No. 585 Th. 1989 tersebut juga disebutkan bahwa tindakan medik yang harus dilaksana-kan sesuai dengan program pemerintah yaitu dalam hal tindakan medik tersebut dilakukan untuk kepentingan masyarakat banyak tidak memerlukan persetujuan pasien atau keluarganya. Dengan demikian dokter atau bidan yang melakukan pelayanan pelaksanaan program KB yang merupakan program pemerintah serta untuk kepentingan rakyat banyak tidak memerlukan persetujuan dari akseptor KB atau keluarganya.
Masalah yang timbul ialah, bagaimana halnya dalam hal pemasangan IUD yang dapat menimbulkan resiko yang tinggi bagi kesehatan seseorang? Bagaimana pula dalam hal kontrasepsi mantap seperti Vasektomi dan tubektomi? Kontrasepsi tersebut dilakukan melalui tindakan pembedahan, apakah "informed consent" tidak diperlukan? Ketentuan tersebut jelas tidak mendukung asas yang dianut dalam program KB, yaitu untuk menciptakan keluarga yang bahagia dan sejahtera sejahtera, karena hak atas persetujuan tindakan medik tersebut mutlak harus ada untuk memberikan rasa aman dan perlindungan bagi akseptor KB.

\section{c. Hak untuk mendapatkan ganti rugi}

Bagi akseptor KB yang mengalami kegagalan dalam pelayanan pelaksanaan program KB berhak untuk mendapatkan ganti rugi. Hal ini dicantumkan dalam penjelasan terakhir dari pasal 20 ayat 1 dari pada UU No. 10 Th. 1992 tentang Perkembangan Kependudukan dan Pembangunan Keluarga Sejahtera yang menyebutkan bahwa,

"Setiap orang memperoleh ganti kerugian akibat kelalaian atau 
kesalahan yang dilakukan oleh maupun non fisik karena kesalahan atau Tenaga Kesehatan dalam mem- kelalaian Tenaga Kesehatan. Perlindungan berikan pelayanan keluarga be- ini sangat penting karena akibat kelalaian rencana". Dalam penjelasan atas atau kesalahan itu mungkin dapat pasal tersebut tidak disebutkan siapa menyebabkan kematian atau menimbulkan yang bertanggung jawab atas ganti rugi, apakah Tenaga Ke-sehatan yang melalaikan pelayanan ataukah BKKBN selaku penanggung jawab program KB."

Bagi Tenaga Kesehatan yang melaksanakan program KB tetap berlaku ketentuan-ketentuan di bidang kesehatan yang diatur dalam pasal 55 UU No. 23 Th. 1992 tentang Kesehatan, yang menyebutkan bahwa:

(1) Setiap orang berhak atas ganti rugi akibat kesalahan atau kelalaian yang dilakukan oleh Tenaga Kesehatan,

(2) Ganti rugi sebagaimana dimaksud dalam ayat (1) dilaksanakan berdasarkan peraturan perundang-undangan yang berlaku.

Selanjutnya dalam penjelasan pasal tersebut ayat (1) menyebutkan bahwa pemberian hak atas ganti rugi merupakan suatu upaya untuk memberikan perlindungan bagi setiap orang atas suatu akibat yang timbul, baik fisik cacat yang permanen. Sedangkan yang dimaksud dengan kerugian fisik adalah hilangnya atau tidak berfungsinya seluruh atau sebagian organ tubuh, sedangkan yang dimaksud dengan kerugian non fisik berkaitan dengan martabat seseorang.

Hak atas ganti rugi bagi akseptor KB dalam pelaksanaan program KB ini akan merupakan fokus kajian dalam tesis ini, mengingat kesadaran hukum bagi akseptor KB terhadap hak ini masih belum memahami, baik mengenai pemahaman hak atas ganti rugi, maupun mengenai prosedur untuk mendapatkannya, serta kepada siapa hak itu dapat dipertanggung jawabkan dan apakah ketentuan perundang-undangan atau peraturan kebijaksanaan yang menyangkut hak atas ganti rugi bagi akseptor KB dalam program KB sudah cukup mengayomi atau melindungi kepentingan para akseptornya?

\section{PENUTUP}

Berdasarkan uraian tersebut di atas, dapat ditarik beberapa kesimpulan 
sebagai berikut:

1. Subyek hukum yang diberi wewenang atas pelayanan kontrasepsi dalam pelaksanaan program KB adalah dokter dan bidan yang diatur dalam Peraturan Menteri Kesehatan R.I. dan Kepala BKKBN No.346/Menkes/Inst/ VI/1983 dan N0.296/HK-011/ E3/1983 tentang Intensif ikasi Pelaksanaan program Kependudukan dan KB dan Peraturan Menteri Kesehatan R.I. No. 572/Menkes/Per/VI/1996 tentang Registrasi dan praktek Bidan.

2. Hak dan kewajiban dalam pelaksanaan pelayanan kontrasepsi program Keluarga Berencana berlaku secara timbal balik, artinya hak bagi tenaga kesehatan merupakan kewajiban akseptor KB begitu sebaliknya hak bagi akseptor KB merupakan kewajiban tenaga kesehatan.

Hak-hak akseptor KB meliputi:

a. Hak untuk memilih macam instrumen atau alat kontrasepsi.

b. Hak kesehatan keluarga.

c. Hak untuk mendapatkan ganti rugi.

\section{DAFTAR PUSTAKA}

Agustin Widjiastuti, "Penyuluhan Keluarga Berencana Dalam Kaitannya Dengan Perubahan Perilaku Warga Masyarakat Terhadap Keluarga Kecil Bahagia Sejahtera", Tesis, Program Studi Magister IImu Hukum, PPS-UA 1996.

BKKBN, Informasi Dasar Program Kependudukan Keluarga Berencana, biro data kependudukan, Jakarta 2982.

Fred Ameln, Kapita Selekta Hukum Kedokteran, Grafikatama Jaya, Th. 1991.

Hermien Hadiati Koeswadji, Hukum, Dinamika Kependudukan dan Lingkungan Hidup, Makalah, Kursus Dasar-Dasar Analisis mengenai Dampak Lingkungan, KMN, KLH, PPKL, LEMLIT, Unair, Surabaya, 28 Juni s/d 4 Juli 1988.

Implementasi Hak dan Kewajiban Para Pihak dalam Perjanjian Menurut Hukum Perdata Terhadap Perjanjian Terapeutik Antara Dokter dan Pasien, Tesis, Program Studi Magister IImu Hukum, PPSUnair, Th 1992.

Raphaella Diah Imaningrum Susanti, "Upaya Hukum Bagi Pasien Sehubungan Dengan Tindakan Medis", Tesis, Program Studi Magister Ilmu Hukum, Program Pascasarjana-Universitas 
Airlangga, Th. 1994.

Rebecca J. Cook, "Formulating Population Policy A Legal Approach" dalam LAWASIA Jurnal, V. 4, 1973.

Sembiring, Demografi, Fakultas

Pascasarjana IKIP Jakarta,
Bekerjasama dengan BKKB, Jakarta, 1985.

Sudikno Mirtokusumo, Mengenal Hukum, Liberty, Yogyakarta, 1991. 